\title{
Does citizen coproduction lead to better urban services in smart cities projects? An empirical study on e-participation in a mobile big data platform
}

\author{
Barbara Allen $^{\mathrm{a}}$, Louise E. Tamindael ${ }^{\mathrm{b}}$, Sarah H. Bickerton ${ }^{\mathrm{a}}$, Wonhyuk Cho ${ }^{\mathrm{a}, *, *}$ \\ ${ }^{a}$ Victoria University of Wellington, New Zealand \\ ${ }^{\mathrm{b}}$ Bhayangkara University, Jakarta, Indonesia
}

\section{A R T I C L E I N F O}

\section{Keywords:}

Citizen-sourcing

Smart cities

E-government

Urban service

Open government

Big data

Digital transformation

\begin{abstract}
A B S T R A C T
With contemporary development of digital technology and smart cities initiatives, citizen co-production has created a new government-citizen interface. However, it remains inconclusive whether such citizen-government collaboration has achieved the fundamental goal of improving service quality for citizens. In this research, we tested the relationship between e-participation as a form of co-production and service performance, using multiple large longitudinal datasets from a smart city mobile platform. The results of the analysis show that citizen e-participation, in providing service feedback, is positively associated with the clearance rate of urban service requests in subdistrict service units, after controlling for various factors. We also found that the effect size of e-participation on service performance varies between different types of city services. E-participation has a stronger relative influence on complex problems that may involve multiple agencies, than with simple routine services.
\end{abstract}

\section{Introduction}

New technologies such as mobile apps, social media, and other web 2.0 tools adopted through smart cities initiatives, have influenced how city and local governments administer their urban services (Khan, 2017; Lee \& Lee, 2014; Sobaci, 2016; World Bank, 2012). One of the most notable influences is the enabling of more active participation by citizens in the co-production of public services, which holds the potential to enhance service quality (Jakobsen, 2013; Löfgren \& Webster, 2019; Thomsen, 2017). The rationale is that urban service provision can achieve better outcomes if it is based on citizen insight. On the other hand, digitally-savvy citizens increasingly see a role in collaboration and co-production with government through online and mobile platforms they know from shopping, banking, and social media, and expect to be involved in changes to service delivery (Bonson et al. Akbar, 2015; Lee \& Porumbescu, 2019).

Such changes may take the form of citizen-driven service delivery or citizen-sourcing in order to meet citizens' needs more responsively (Allen \& Wade, 2011; Nam, 2012; Sorn-in, Tuamsuk, \& Chaopanon, 2015). Governments want to better understand their citizens in order to offer improved service delivery, which in turn is expected to contribute to city governments' goals for quality of life and sustainability. For example, locational information collected through participatory platforms is increasingly relevant to smart cities projects and citizens are becoming essential producers of (big) data (Löfgren \& Webster, 2019). Despite the promise of smart cities and citizen co-production for improved services, little is known in the literature about whether technology-facilitated citizen co-production has actually realized this promise.

The literature tends to only offer frameworks for co-production and e-participation, often purely theoretical (Allen, Juillet, Paquet, \& Roy, 2005; Islam, 2008; Lee \& Kim, 2018; Phang \& Kankanhalli, 2008; Pirannejad \& Janssen, 2019), and does not provide "empirical proof" (Holgersson \& Karlsson, 2014; McBride, Aavik, Toots, Kalvet, \& Krimmer, 2019; Scherer, Wimmer, \& Strykowski, 2015). Islam (2008), as well as Susha and Grönlund (2012), suggested that empirical study is 'immature' on the topic of e-participation in the context of citizen coproduction. Evidence is lacking also in regard to which aspects of smart city projects do contribute to the goal of improving the quality of service delivery (Tang \& Ho, 2019). The literature on Open Government lacks evidence on the outcomes of collaboration between citizens and governments, often referred to as 'smart collaboration' (Attard, Orlandi, Scerri, \& Auer, 2015; Meijer \& Bolivar, 2016), that can be enabled by smart cities initiatives (Feroz Khan, Young Yoon, Kim, \& Woo Park, 2014; Scherer et al., 2015; Wirtz \& Birkmeyer, 2015).

The motivation for this article is to close the gap in this literature,

\footnotetext{
* Corresponding author.

E-mail address: wonhyuk.cho@vuw.ac.nz (W. Cho).

${ }^{1}$ Author order is alphabetical. The authors contributed equally to this article.
} 
focusing on examining the impact of citizen e-participation in co-production on service performance. We test whether an increased level of e-participation from citizens is associated with an urban service quality improvement in various city service areas, using a large longitudinal dataset obtained from the 'Qlue MyCity' (hereafter Qlue) mobile application. We then compare effect size of e-participation to service type, given that the nature of the process for resolving urban issues may differ depending on the various service areas. Qlue provides a mapbased mobile platform with social media integration so that citizens can participate in co-production of government's service delivery system.

This article contributes to the literature on citizen co-production, eparticipation, citizen-sourcing/crowdsourcing, and open government. Previous citizen co-production research has primarily focused on citizen activities such as identifying or reporting problems and needs (Díaz, Carroll, \& Aedo, 2016; Linders, 2012; Macintosh, 2004) and much less attention has been given to the role of citizen's monitoring and evaluation (Scherer et al., 2015; Susha \& Grönlund, 2012), that this study is analyzing empirically. Most literature on e-participation, on the other hand, focuses on the policy-making process (Callahan, 2007; Edelmann, Krimmer, \& Parycek, 2008; Islam, 2008; Macintosh, 2004; Reddick, 2011; Tai, Porumbescu, \& Shon, 2019; Toots, 2019), yet discussion related to participation in service delivery has been much less explored.

We begin this paper by looking at the wider literature on co-production, e-participation, and related concepts. We then consider smart cities and the place of service performance and service feedback provision in their context. The sections thereafter will present the data and methods used, as well as the findings, concluding with a discussion of those findings.

\section{Literature review}

\subsection{Citizen co-production: Participation in service delivery and citizen- sourcing}

Digitalization of government can mean greater opportunities for citizen co-production. Co-production has evolved considerably since its appearance in Public Administration literature in the late 1970s (Allen, Wade \& Dickinson, 2009; Bovaird, 2007; Brudney \& England, 1983; Whitaker, 1980) and has been reimagined in the Information Management field to have much more impact due to ongoing advancement in technology (Johnston \& Hansen, 2011). With the instantaneous nature of ICT-enabled processes, co-production has become a realistic form of deeper involvement of citizens with government (Chatfield \& Reddick, 2018a,b) while unlocking opportunities for citizens to do more and better for themselves (Johnston \& Hansen, 2011; Linders, 2012).

Included in the context for co-production is the financially tighter environment of governments around the globe, where budget-constrained governments have tried to seek innovative solutions to providing public services more efficiently and cost-effectively. The hope here lies with the interactive nature of new technologies (Allen et al., 2004; Linders, 2012). This aspect is closely related to a slightly different term, 'co-provision', by Ferris (1984), that describes the expectation for citizen involvement to reduce the amount of resources needed by government to run a service. Both the efficiency-oriented focus of coprovision, and wider focus on citizen-government relationships from co-production, are relevant to the realities of city and local governments. What is sought particularly in many developing countries is a cost-effective solution for problems of rapid urbanization (Im, Cho, \& Porumbescu, 2011), while managing relationships with citizens for maintaining a government's legitimacy.

Recent literature on online co-production by citizens has paid particular attention to concepts of citizen- and crowd- sourcing (Harrison \& Johnson, 2019; Schmidthuber \& Hilgers, 2018). Crowd-sourcing is a more well-known term, but gaining "collective wisdom" is what citizensourcing and crowd-sourcing have in common (Ebner, Leimeister, \&
Krcmar, 2009; Glaeser, Hillis, Kominers, \& Luca, 2016; Hetmank, 2013; Maheshwari \& Janssen, 2014). Citizen-sourcing efforts by government are focused on integrating citizens into administrative processes through increased openness in order to achieve quality service improvement, transparency, participation, and public value creation (Chatfield \& Reddick, 2018a,b; Hilgers \& Ihl, 2010; Hossain \& Kauranen, 2015). Citizen-sourcing is defined as citizen support of government for responsiveness and effectiveness, and it can take the form of (i) crowd-sourcing and co-delivery, (ii) consultation/ideation for designing services, and (iii) citizen reporting to monitor services (Linders, 2012; Nam, 2012), which is very relevant to the research theme of this article.

In the co-production literature, citizen participation forms a fundamental tenet (Alford, 2002, 2009; Jakobsen, 2013; Sharp, 1980)—for example, one of the propositions within the pioneering work of Whitaker, "Coproduction: Citizen Participation in Service Delivery," is that citizens can affect the execution of programmes via their direct participation in service delivery. This is through such activities as citizen requests for assistance, citizen provision of assistance, and citizengovernment mutual adjustment (see Whitaker, 1980). Whereas citizen participation was typically viewed as a way to influence public policy (Arnstein, 1969; Callahan, 2007; Jamal, Kizgin, Rana, Laroche, \& Dwivedi, 2019; Phang \& Kankanhalli, 2008; Reddick, 2011) it also has become a growing part of service delivery (Lee, Park, \& Lee, 2019).

Participation, in general, is a means of improving both the performance and accountability of a bureaucracy portrayed as outdated, unrepresentative, and underperforming (Bryson, Quick, Slotterback, \& Crosby, 2013; Im, Lee, Cho, \& Campbell, 2014; Neshkova \& Guo, 2011; Yang \& Callahan, 2007). This can be in the form of policy feedback or via contributing to programmes (Wichowsky \& Moynihan, 2008). Moynihan (2003) argues that citizen participation refers to the interaction between citizens and government to provide feedback at different points of policy formulation/implementation. Relatedly, Feeney and Welch (2012) define participation as opportunities for the public to offer input/feedback into government policies, programmes, and services. Moynihan, Feeney and Welch's conception of citizen participation is similar to that of Whitaker's (1980: 242), in that citizens can collaborate with the government to produce services by requesting assistance from, providing assistance to, and interacting with public agents to adjust each other's service expectations. Providing assistance and interacting with agents means that citizens can request a service from officials (one-way communication), but can also give input/feedback to the public agents (two-way communication) (Firmstone \& Coleman, 2015; Ho \& Cho, 2017). Hence, citizen participation in service delivery can contribute to programme success (Neshkova \& Guo, 2011; Voss, Roth, Rosenzweig, Blackmon, \& Chase, 2004; Yang \& Pandey, 2011).

\subsection{E-participation in monitoring service performance and open government}

E-government has enabled different forms of participation, and the intersection of the two can be labeled e-participation (Bertot, Jaeger, \& Grimes, 2010; Ho, 2002; Naranjo-Zolotov et al., 2019; Sagarik, Chansukree, Cho, \& Berman, 2018; Zheng, 2017). Zheng (2017) suggests that citizen participation via ICT utilization can help governments improve service delivery, and his argument is in line with that of Reddick's (2011) that improvement in service delivery is influenced by e-participation. Citizen participation in providing information on public perception of a service can ultimately increase a government's accountability. This is because government is supposed to develop a reputation for consistently meeting citizens' expectations for service quality (Berry, Zeithaml, \& Parasuraman, 1990; Kim \& Cho, 2014). In this context, e-participation also is viewed as a significant part of recent developments in open government or social government (also known as SocialGov or s-Government) initiatives (see Feroz Khan et al., 2014; Scherer et al., 2015). 
A section of the participation literature defines e-participation as the use of ICT to support decision making (Macintosh, 2004; Medaglia, 2012; Porumbescu \& Grimmelikhuijsen, 2018). The United Nations (2016) takes this further, defining e-participation "as the process of engaging citizens through ICTs in policy, decision-making, and service design and delivery in order to make it participatory, inclusive, and deliberative" (p. 6). It is clear that the widespread use of the internet has opened up possibilities for participation that simply were not available before. Reddick (2011) proposed hierarchical measures of eparticipation in government, ranging from one-way interaction (managerial), two-way interaction initiated by government (consultative), and finally his highest form of e-participation; two-way interaction initiated by citizens with government and vice versa (participatory). Whereas Sæbø, Rose, and Flak (2008: 400) define e-participation as the transformation of participation in consultative processes via mediation by ICT, our focus does not suggest a transformation of participation through 'e-engagement', but rather that a more incremental increase in participation occurs with the support of active citizenship via technology.

While we place e-participation within co-production more widely, we specifically position it amongst the work of Susha and Grönlund (2012) and Linders (2012). Linders' (2012) typology of classifying citizen co-production initiatives provides a location for the type of eparticipation our research focuses on; specifically the 'citizen reporting' aspect of the overarching category of 'citizen-sourcing'. 'Citizen reporting' is enabled through the use of ICT contemporarily by giving citizens the ability to report using their mobile phones, and particularly by issuing a tracking number which enables citizens to track progress on service delivery, as well as hold the government to account for promptness and quality (Linders, 2012). Susha and Grönlund (2012)'s work in the field of e-participation research can thus be seen as similarly located, but from an e-participation orientation, whereby institution-initiated applications (such as e-information, e-compliance, and importantly e-service, amongst others) are connected to e-participation concepts of self-efficacy and goal-perception. It is this common location of the contributive service app that connects both co-production literature and e-participation literature, with the latter emphasizing the effects of societal inclusion, and the former service delivery.

Given the various aspects of e-participation that exist as forms of coproduction, we operationalize it with a focus on the citizen's contribution to e-monitoring (feedback on the completion of service as positive or negative) - this aspect of e-participation has been labeled by various authors as "monitoring of public services" (Schere et al. Akbar, 2015) and "evaluation of policy in action" (Macintosh, 2004). The rationale for focusing on the e-feedback and e-monitoring aspects of citizen participation is that e-participation generates a feedback mechanism that provides a way for citizens to communicate with service authorities, who then may use the feedback to improve programmes. This is something which is an often-overlooked factor in explaining service performance in the literature (Wichowsky \& Moynihan, 2008). A considerable body of literature suggests that one important aspect of service performance is to know the level of satisfaction by feedback processes (Kang, Cho, \& Jung, 2012.; Forbes, 2008; Hall \& Aristigueta Akbar, 2015; Poister, Hall, \& Aristigueta, 2015; Zheng, 2016). The role of e-participation in providing service feedback is also an important part of recent developments in Open Government-advancements in technology have enabled a new level of openness in government, whereby agencies and service units make their service performance information available for public scrutiny via various mobile planforms.

Despite the increased interest in citizen feedback as a way of addressing government performance issues (Kasymova \& Schachter, 2014), the extent to which coproduction, and e-participation in its modern ICT enabled form, contributes to service quality is not well understood. In particular, much less is known about whether participation enabled by government adoption of new smart city platforms, such as mobile applications, does actually result in the promised advancement of service performance. This missing link between eparticipation and service performance is a significant gap, given that delivering urban services to citizens is at the heart of what cities do and is crucial in shaping public trust in government (Porumbescu, 2017; Im et al., 2014; Neshkova \& Guo, 2011). Based on the theoretical argument in the literature on co-production and e-participation we reviewed, this article proposes a model that associates service performance with the level of e-participation in co-producing service feedback. There have been a few efforts to analyze the participation-performance nexus either in individual case studies and or in compilations of case-study research, but they have produced mixed results (see Beierle \& Cayford, 2002; Im \& Cho, 2010; Porumbescu, 2016; Moynihan, 2003; Yang \& Pandey, 2011).

\section{Research context}

\subsection{Smart cities under rapid urbanization in developing countries}

In the last two decades, smart city initiatives have emerged as one of the most dominant approaches taken by city governments worldwide in terms of technology-based solutions to urban problems. Rapid urbanization and mega-urbanization, particularly in post-colonial nations, often exceeds the fiscal capacity of the governments to fund supportive public infrastructure (Adelekan et al., 2015; Campbell \& Cho, 2014; Cho, Im, Porumbescu, Lee, \& Park, 2013). As such, city administrations have sought new approaches to urban planning, including the 'smart city'. In academia, the Smart City as a concept is a fast-growing domain of study across multiple disciplines. As can then be expected, the definition of what exactly a smart city is has been contested and increasingly explored in scholarly discussion, but most definitions tend to relate to the importance of technology as an enabler of improved service delivery (or better use of resources), seeking synergies between social structures and new technology (Albino, Berardi, \& Dangelico, 2015; Hur, Cho, Lee, \& Bickerton, 2019; Meijer \& Bolivar, 2016).

Meijer and Bolivar (2016) analyzed the different approaches in smart city literature, and identified three different foci; a technology focus (smart technologies), a human resource/capital focus (smart people), and a governance focus (smart collaboration). Out of these three foci, the locus of this article is closest to the governance focus, since we test the impact of citizen collaborative involvement on Jakarta's outcome as a smart city. The governance- and collaborationfocused approaches include the argument that in order to be 'smart' in an effective and practical sense, cities require active citizen participation. It is within this aspect of smart city literature that this research is located. Aguilera, Peña, Belmonte, \& López-de-Ipiña (2017) define this approach as being in contrast to the "smart city in a box" solution provided by big corporations, shifting instead to including crowdsourced or citizen-sourced data and participation, via the creation of user-centric mobile services. Given the app-focused smart city approach of the Jakartan Qlue initiative, this shift is reflected in this research.

There has been very little study of smart cities in the developing world, even given that the rapid urbanization there is one of the biggest concerns for these nations. Vu and Hartley (2017) have suggested several distinctive characteristics of smart city initiatives in the context of developing nations, known as the smart cities development (SCD) perspective. For example, they found that smart city development projects in lower-income countries have stronger central support from national governments and tend to be integrated into national strategies, while the smart city projects from more developed nations are initiated by the cities themselves. Another defining characteristic of smart city development is the emphasis on governance accountability and transparency. A strong focus on improving city and local governments' capabilities for higher service performance is also identified as a priority in smart city development projects. Neirotti, De Marco, Cagliano, Mangano, and Scorrano (2014) reviewed the smart city initiatives of 70 cities internationally and found that cities in more 
wealthy countries are more active in 'hard' domains such transport, energy, and buildings while developing countries are more focused on 'soft' domains such as governance, transparency, social inclusion, and government capabilities, which is consistent with $\mathrm{Vu}$ and Hartley (2017)—and the smart city projects in Jakarta, Indonesia, share these characteristics.

\section{2. 'Qlue MyCity' and smart cities initiative}

In Indonesia, local government has begun to utilize mobile apps, the web, social media, and social networking to deliver its services-in addition to attempting to boost various e-participation initiatives with smart city projects. For example, Bandung City has one of the most well-known cases of ICT utilization that involves citizens in city service delivery (Setiawati \& Pratiwi, 2015) - the city adopted ICT to encourage better communication and collaboration between government and citizens, and citizens have reported better access to the government in requesting a service, conveying feedback, and real-time critique (Kishnani, 2014).

Jakarta is another Indonesian city that has developed smart city initiatives. Since 2014, the local government in Jakarta has developed and used, amongst others, the mobile app Qlue MyCity, with the specific intention of improving service performance for citizens (Akbar, 2015; Syafputri, 2014). The rationale for this is rooted in the low quality of public services reported in Jakarta for a long period of time-according to the Ombudsman Republik Indonesia (2015), the delivery of public services in Jakarta does not meet the standards set forth in Law 25/2009, particularly in regards to service completion rate, availability of transparent service procedures, and availability of complaint handling services.

Qlue MyCity is a map-based integrated reporting and monitoring platform utilizing citizen participation to identify city problems and provide service feedback on those problems. Through this platform, citizens can report such things as clogged drains, waste disposal issues, broken street lights, damaged roads, and floods, amongst others, and request a public service response to such. Fig. 1 outlines the workflow and decision points for the Qlue system, including the areas of responsibility across the top of the table, and down the side where the app handles handoff and reception of data during the service request process.

Citizen service requests and feedback from the mobile smartphone platform automatically enter the city's database and are delegated to the relevant city service unit, as well as to relevant individual city officials, as presented in Fig. 1. Once a problem is resolved, the app displays a picture of how the problem has been resolved by city services, while allowing users, both the citizens who reported the problem and others who have seen the issue, to rate their satisfaction with the outcome. Since Qlue launched, the app has been downloaded $>$ 600,000 times Ananta (2017) and Nurito (2016) found that citizens feel that they can more easily report problems in their neighbourhood, and give feedback on the services a lot more effectively (Dachland, 2016). Before Qlue was launched, citizens in Jakarta had to send a letter to the agency specific to a service to request that service, and the request wouldthen get a response from officers after a few months (Yuliani, 2015).

From January to February 2017, there were a total of more than fifty thousand service requests delegated to 261 sub-district officials in Jakarta. Users are required to post a photo of a reported issue using the app, and the relevantly delegated official is also required to do the same when the problem is solved-the posting of a photo is required in order to minimize false reports. In the reporting process, the app also uses the GPS location function in a user's smartphone to narrow down where the issue is located. Given the vast area of Jakarta $\left(664 \mathrm{~km}^{2}\right)$, and with the population having reached 9.98 million people (Ministry of Home Affairs, 2015), citizen involvement is expected to make the identification and resolving of such problems more effective.
The user interface of Qlue is carefully designed to be compatible with social media outlets, since the social networking service (SNS) landscape in the country is favorable to it. In Indonesia, the total number of active social media users is 106 million, or $40 \%$ of the total population (Kemp, 2017; Savitri Hartono, 2018). Of these, 92 million users, or $35 \%$ of the total population, access social media from mobile devices. The average time an Indonesian spends on social media a day is over $3 \mathrm{~h}$. When compared to other cities internationally, Jakarta is the 4th largest city in the world in terms of the number of active Facebook users. These figures could indicate that local government in Indonesia has quite the opportunity to increase citizen participation in co-production through the use of ICT, especially mobile apps and social media, in order to improve the performance of public service delivery (Lucas, 2007;Siagian, Sumaryana, Widianingsih, \& Nurasa, 2019).

\section{Data and methods}

This research uses Qlue data as well as other city-sourced data. The Qlue data was obtained from the Qlue app system over a two-month period, from January 12017 to February 28 2017. Through the app, citizens and officials file reports, the data from which comprised various elements such as report category (e.g., waste disposal, potholes, illegal parking, etc.), the location where the problem occurred (the app uses the phone's GPS), time when the problem was reported, and how many users participated in giving service feedback. The unit of analysis was the 261 sub-districts of Jakarta. A sub-district is the lowest level of the government's urban service administration in Indonesia. The Jakarta area consists of 5 municipalities and 267 sub-districts, and we used data from 261 sub-districts because of missing observations. The missing sub-districts are in the Kepulauan Seribu, also known as Thousand Islands Regency, and because of the distinct nature of the Regency from the mainland Jakarta, the Qlue system was not fully adopted in the region.

The hypothesis proposed in this research is that e-participation in the form of providing service feedback contributes positively to the performance of service delivered by the Jakarta's subdistricts. We operationalized the dependent variable, service performance, as the service clearance rate in a given period in a subdistrict. Poister et al. (2015) suggested that the most common dimensions of public service performance are turnaround time, accuracy, thoroughness, accessibility, convenience, courtesy, safety, and clearance rate-this research will use one such dimension, clearance rate, as the variable for service performance, due to data constraints. Clearance rate is calculated as the percentage of service requests with a completed status. Clearance rate may capture one of many aspects of the true performance outcome, and may be one of the easiest internal measures to game, rather than outcomes that have more salience for citizens (Cho \& Ho, 2018; Hatry, 1999; Van Ryzin, 2007). However, Kelly and Swindell (2002) suggest that service output measures like clearance rate generally correlate with citizen outcome. Even if they do not correlate in a couple of service areas, it does not diminish the usefulness of the output measure because internally measured output performance has its own administrative meaning. Further, this research links what citizens notice to what service output is produced, which makes the performance argument of this article more comprehensive.

The explanatory variable, citizen e-participation through the Qlue mobile app, is operationalized by the volume of citizens' service feedback participation via the mobile app, as measured by its quantity (feedback count) in a given period (a month) in a sub-district. We controlled for quantity of service requests, sub-district personnel size, population size, geographical size $(\mathrm{km} 2)$ in a region, and district dummies to consider district-specific fixed effects. Table 1 shows the descriptive statistics of variables.

In terms of Qlue's workflow presented in Fig. 1, e-participation and quantity of service request variables are associated with the process in the first column from the left ('Public'), while sub-district personnel 


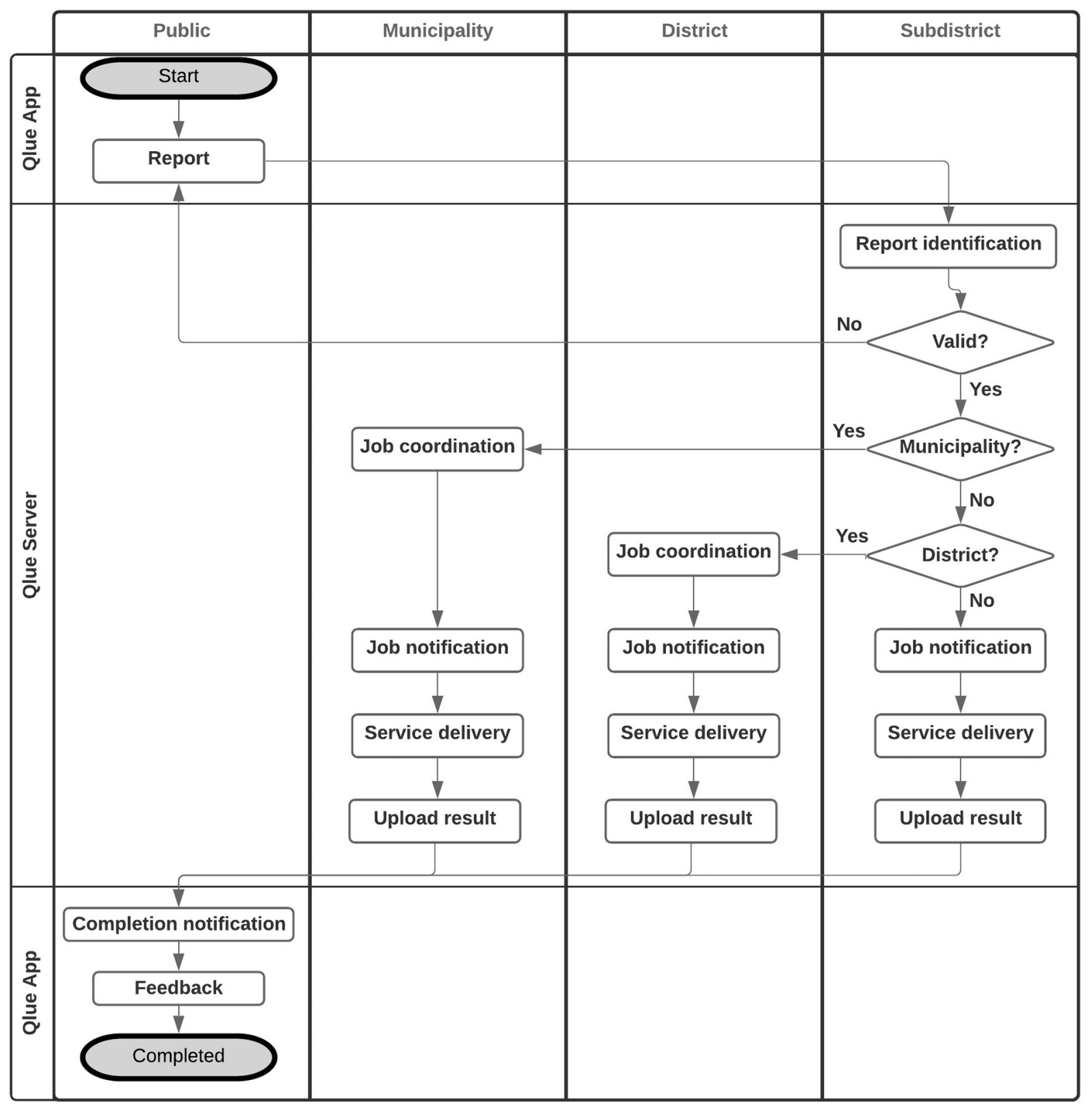

Fig. 1. Qlue Workflow (note: adopted from Qlue webpage). Qlue - Smartcity (2017)

Table 1

Descriptive statistics of variables.

\begin{tabular}{llllll}
\hline Variable & $N$ & Mean & Std. dev. & Min. & Max. \\
\hline $\begin{array}{l}\text { Service performance: Clearance } \\
\quad \text { rate (\%) }\end{array}$ & 261 & 78.73 & 16.41 & 21.74 & 100.00 \\
E-Participation & 261 & 777.85 & 1645.07 & 2 & 12,908 \\
Quantity of service request & 261 & 195.08 & 181.54 & 8 & 1085 \\
Sub-district personnel size & 261 & 75.91 & 24.08 & 42 & 183 \\
Population size & 261 & $38,214.39$ & $21,644.58$ & 2882 & 150,201 \\
Geographical size $\left(\mathrm{km}^{2}\right):$ & 261 & 2.50 & 2.12 & 0.27 & 13.07 \\
$\quad$ Service area & & & & & \\
District dummies & & & & & \\
$\quad$ Central Jakarta & 261 & 0.17 & 0.37 & 0 & 1 \\
$\quad$ East Jakarta & 261 & 0.25 & 0.43 & 0 & 1 \\
$\quad$ North Jakarta & 261 & 0.12 & 0.32 & 0 & 1 \\
$\quad$ South Jakarta & 261 & 0.25 & 0.43 & 0 & 1 \\
$\quad$ West Jakarta & 261 & 0.21 & 0.41 & 0 & 1 \\
\hline
\end{tabular}

Note: Original data prior to log transformation. size, population size, and geographical size variables are associated with the process in the 4th column ('Subdistrict')—district dummy variables are associated with the 3rd column ('District'). The average clearance race of the sub-districts is $78.74 \%$, while there are two subdistricts with clearance rate $30 \%$ and below. During January to February 2017, Qlue received 203,019 pieces of citizen feedback from users. In terms of this volume of citizen service feedback, there are three sub-districts that received $>10,000$ pieces of service feedback in two months, while six sub-districts received less than ten. The highest amount of feedback was received by the Kebon Pala sub-district in East Jakarta with total of 12,908 in two months.

Regarding the quantity of service requests we controlled for, the total number of service requests received in the period was 50,918. The highest number of requests received was in the sub-districts of Cengkareng Barat and Cawang, with 1085 and 1023 service requests respectively. The personnel size variable was calculated by the total number of people working in the Public Facility Maintenance Agency in each sub-district-personnel numbers varied from 42 to 183 according to the population and the size of the area of each sub-district. 
Table 2

Regression for service performance.

\begin{tabular}{|c|c|c|c|c|c|c|}
\hline & \multicolumn{3}{|l|}{ Base Model } & \multicolumn{3}{|c|}{ Lagged Model } \\
\hline & Coeff. & Std. Err. & Beta & Coeff. & Std. Err. & Beta \\
\hline Constant & $-0.382^{*}$ & 0.175 & & -0.293 & 0.225 & \\
\hline E-participation & $0.113^{* * *}$ & 0.014 & -0.652 & & & \\
\hline E-participation (t-1) & & & & $0.076^{* * *}$ & 0.016 & 0.406 \\
\hline Quantity of service request & $-0.126^{* * *}$ & 0.024 & -0.462 & $-0.063^{*}$ & 0.030 & -0.197 \\
\hline Sub-district personnel size & 0.166 & 0.086 & 0.199 & 0.120 & 0.110 & 0.123 \\
\hline Population size & 0.000 & 0.024 & -0.001 & -0.007 & 0.030 & -0.017 \\
\hline Geographical size (km2) & -0.024 & 0.029 & -0.078 & -0.020 & 0.037 & -0.057 \\
\hline Central Jakarta & $-0.068^{* *}$ & 0.020 & -0.237 & $-0.086^{* *}$ & 0.026 & -0.254 \\
\hline North Jakarta & $-0.089 * * *$ & 0.022 & -0.265 & $-0.094 * *$ & 0.028 & -0.239 \\
\hline South Jakarta & $-0.039^{*}$ & 0.017 & -0.156 & -0.037 & 0.022 & -0.127 \\
\hline West Jakarta & $-0.063^{* *}$ & 0.019 & -0.238 & $-0.077^{* *}$ & 0.025 & -0.249 \\
\hline Adjusted R-squared & 0.286 & & & 0.147 & & \\
\hline $\mathrm{N}$ of obs. & 261 & & & 261 & & \\
\hline AIC & -1238.40 & & & -1107.65 & & \\
\hline
\end{tabular}

Note: Statistically significant at ${ }^{*} p<.05 * * p<.01 * * * p<.001$.

Population refers to the total number of persons in each sub-district-the smallest being Karet Semanggi (2882), while the most populous is Kapuk $(150,201)$. The service area, which is the size of each sub-district in square-kilometers, varies from 0.27 to 13.07 .

When running the regressions, classical assumption tests, including Kolmogorov-Smirnov and Shapiro-Wilk tests, and a normal quantile plot of the residuals diagnostic, were performed with no significant issues being found in regards to normality, homoscedasticity, linearity, or statistical independence. The original data for all variables except the district dummy were transformed using log transformation. Additionally, we conducted analyses with the time-lagged measure (eparticipation a month lagged) and different service types, as the most likely impact on clearance rate is in the sequent period.

\section{Findings}

Table 2 presents the results of the analysis. An increase in e-participation, in a form of providing service feedback, is positively related to better service performance, and this relationship is statistically significant at the 0.001 level. This result is consistent in the model with the time-lagged (one month) e-participation variable. The results support the hypothesis that e-participation in the mobile app, as a form of provision of service feedback, contributes positively to the performance of service delivered by the Jakartan subdistrict service units; the subdistricts that received a higher quantity of feedback have a higher clearance rate than sub-districts which received a lower quantity of feedback. This significant relationship is found after controlling for various factors, and amongst the control factors, quantity of service request is negatively associated with service performance, in that the sub-districts with higher service demands have more challenges in meeting performance expectations.

Table 3 shows the category of services requested by users. In the raw data obtained from Qlue there are 41 categories of reports or service requests. We re-categorized them into 11 categories to be more concise, since some of the original categories have similarities. During January to February 2017, waste disposal received the highest volume of service requests. Waste disposal also received the most feedback and the highest clearance rate. The high demand for waste-related services is not surprising given that waste disposal has been a considerable issue for Jakarta.

Table 4 shows the relative strength of the e-participation variable to other predictors by service type, as shown in beta coefficient. The size of the effect of waste disposal, illegal advertisement are lower compared to other models, probably due to the simplicity of the job solving the problem. Service requests for waste disposal and illegal advertisement are requests requiring routine work done by individual officers and their specific teams in every subdistrict, while the other categories, such as damaged roads, are more complex work, and can involve other agencies such as Transport Agency, Public Work Agency, Public Order Agency, Social Affairs Agency, and Police. Previous research on the participation-performance relationship posits that the positive performance outcome of participation is better realized when there is a learning process that develops capacity to create new solutions. As such, the results of this research may suggest that the inter-agency learning network is more capable in dealing with more complex service requests when compared to that of intra-agency one-but this is an untested interpretation of the results, and future study is required to investigate this possible explanation.

\section{Discussion}

Using the Qlue application data, this study offers evidence that eparticipation, in the form of service feedback, has a positive contribution to the performance of the service delivery provided by subdistrict service units. In a subdistrict with a higher number of e-feedback reports, the clearance rate is higher for the service unit of the region. The findings suggest that citizen co-production in regard to e-monitoring and providing e-feedback can be an important tool for smart city projects to improve the performance of urban services. These findings have practical significance for local government administrations, especially in the development of smart city initiatives.

City officials and mangers can thus, at least in part, address a city's urban problems by engaging more public e-participation in order to monitor government performance. The volume of citizen reporting and service feedback in the data shows that Jakartan citizens are willing to participate in, and pay attention to, processes to improve public service delivery. During the period of study of two months, there were $>$ 50,000 citizen reports, and $>200,000$ pieces of feedback. Prior to the adoption of this app, citizens expressed high levels of frustration regarding city service delivery sporadically through social media without resolution (Anggraini, 2016). Canares, Putri, Karlina, and Tanaya (2017) found that in general Jakartan citizens are also hesitant to interact directly with government officials face to face-this may be due to the administrative burden associated with the face to face processes (see Moynihan, 2003). Qlue appears to give citizens a channel to voice their concerns electronically instead. Moreover, with their privacy guaranteed (the user is allowed to report anonymously), citizens feel safer when they report such problems (Canares et al., 2017; Cho, 2017).

The willingness of Jakartan citizens to participate in public service co-production and delivery can be explained differently by the study undertaken by Holgersson and Karlsson (2014). They suggest that a citizen who is satisfied with public service prefers to not participate 
Table 3

Summary statistics by service type.

\begin{tabular}{|c|c|c|c|c|c|c|}
\hline \multirow[t]{2}{*}{ Service type } & \multicolumn{2}{|c|}{ Total number of Service request } & \multicolumn{2}{|c|}{ Total number of Service feedback } & \multirow{2}{*}{$\begin{array}{l}\text { Clearance rate } \\
\text { Average } \%\end{array}$} & \multirow{2}{*}{$\begin{array}{l}\text { Turnaround time } \\
\text { Average Hour }\end{array}$} \\
\hline & Total & $(\%)$ & Total & $(\%)$ & & \\
\hline Waste disposal & 9769 & (19.19) & 49,217 & $(24.24)$ & 95.14 & 42.61 \\
\hline Illegal parking & 8244 & (16.19) & 46,653 & (22.98) & 63.15 & 299.30 \\
\hline Public utility & 7638 & (15.00) & 20,645 & $(10.17)$ & 75.19 & 182.58 \\
\hline Illegal advertisement & 6672 & (13.10) & 23,336 & (11.49) & 84.46 & 75.07 \\
\hline Code Violation & 6301 & (12.38) & 19,630 & $(9.67)$ & 72.84 & 153.01 \\
\hline Damaged road & 3039 & $(5.97)$ & 6549 & $(3.23)$ & 63.04 & 262.07 \\
\hline Illegal street vendor & 2540 & (4.99) & 10,702 & $(5.27)$ & 43.05 & 287.43 \\
\hline Drainage/flood mitigation & 2433 & $(4.78)$ & 9542 & $(4.70)$ & 74.15 & 96.23 \\
\hline Traffic congestion & 1585 & $(3.11)$ & 6821 & $(3.36)$ & 58.74 & 236.77 \\
\hline Local election & 1052 & $(2.07)$ & 3905 & (1.92) & 62.40 & 77.27 \\
\hline Others & 1643 & $(3.23)$ & 6019 & $(2.96)$ & 65.61 & 140.98 \\
\hline Total & 50,916 & $(100.00)$ & 203,019 & (100.00) & & \\
\hline
\end{tabular}

Table 4

Regression by Service Type: E-participation Statistics.

\begin{tabular}{llllll}
\hline $\begin{array}{l}\text { Service Type (E- } \\
\text { participation) }\end{array}$ & Coeff. & Std. Err. & Beta & Adj. R-Sq & AIC \\
\hline Damaged road & $0.222 * * *$ & 0.026 & 0.614 & 0.325 & -825.53 \\
$\begin{array}{l}\text { Drainage/flood } \\
\quad \text { mitigation }\end{array}$ & $0.075 * * *$ & 0.016 & 0.437 & 0.137 & -1082.09 \\
Illegal parking & & & & & \\
Local election & $0.209 * * *$ & 0.024 & 0.634 & 0.395 & -776.11 \\
Public utility & $0.033 *$ & 0.014 & 0.237 & 0.037 & -1250.41 \\
Traffic congestion & $0.173 * * *$ & 0.017 & 0.669 & 0.380 & -1031.94 \\
Illegal advertisement & $0.121 * * *$ & 0.020 & 0.460 & 0.283 & -941.92 \\
Illegal street vendor & $0.044 * *$ & 0.014 & 0.328 & 0.138 & -1185.80 \\
Code Violation & $0.203 * * *$ & 0.025 & 0.518 & 0.389 & -722.48 \\
Waste disposal & $0.174 * * *$ & 0.021 & 0.670 & 0.281 & -932.07 \\
Others & $0.020 * *$ & 0.008 & 0.256 & 0.150 & -1518.38 \\
\hline
\end{tabular}

Note: Statistically significant at *p $<.05 * * \mathrm{p}<.01 * * * \mathrm{p}<.001$. Coefficient, standard errors, and Beta values are of e-participation variable.

(Holgersson \& Karlsson, 2014). This argument is in line with Stipak (1979) who pointed out that people tend to pay less attention to city services so long as service performance is within some adequate range. That the performance of public service delivery in Jakarta is still far from such an expectation is one of the reasons for citizens to participate in improving the city's service delivery (Canares et al., 2017; Lucas, 2007). As above, this is an untested possible explanation, and future work is required on this.

The findings of this study contribute to the literature on citizen coproduction and e-participation, by providing empirical evidence on the role of citizen e-monitoring of public services. E-participation in service delivery, as well as its impact on performance, have been under-explored and the results of our analysis broaden our understanding of the phenomena. With respect to the Smart City literature, this article supports the idea that 'smart collaboration' is an important element of ICTenabled governance (Allen, Juillet, Paquet, \& Roy, 2001; Campbell, 2018; Im, Cho, Porumbescu, \& Park, 2012; Meijer \& Bolivar, 2016), and our findings illustrate how this conceptual framework of ICT-assisted collaboration can be observed in a real-life case of Smart City initiatives. The empirical evidence in this study also supports the theoretical argument of the merit of open government in improving accountability mechanisms through advancements in technology that enables more citizen monitoring.

Susha and Grönlund (2012) identified the immaturity of research design and a lack of comprehensive methodology as limitations within e-participation research-the authors cited the works of Macintosh, Coleman, and Schneeberger (2009), Sæb $\emptyset$ et al. (2008), Medaglia (2012), Macintosh and Whyte (2008) as those that noted this gap. The solutions identified by Susha and Grönlund (2012) involved employing more sensitive research designs capable of measuring effect and recognizing the full complexity of domains. Given that previous work in this area has involved such things as 'one-shot' perceptual citizen surveys as data, which can be seen as being located within the identified constraint, our research instead uses a large data set of good quality, as well as different forms of data collected independently and (crucially) over a period of time (as opposed to the more 'snapshot' nature of citizen surveys). As such, this article begins to bridge this gap of methodological robustness and maturity within the field of e-participation.

\section{Conclusion}

This study provides initial empirical evidence that citizen e-participation in coproduction is able to increase the performance of service delivery-a link more often assumed than tested. In a more specific context, the findings show that feedback and monitoring from citizens via a smart city platform increases the percentage of resolved problems. Interestingly, citizen e-participation in service delivery appears to have a relatively stronger influence on complex problems such as damaged roads, which may require multiple agencies to solve the problem, and may need more time to be resolved. This is in contrast to simple problems, such as routine work like waste problems, where the relative influence of the citizen e-participation is lower.

Both theoretical implications and practical value emerge from these results. By showing how e-participation in co-production improves the performance of government service delivery, this study adds empirical evidence of e-participation and co-production to smart city projects, a relatively new topic in the literature. Along with the widespread adoption of smart city practices, these results might also be relevant for city and local policy makers. Policy makers could pay more attention to smart city platforms that better facilitate citizen e-participation in monitoring government service delivery. By enabling citizen co-production, the openness and transparency of government could ultimately lead to better public sector performance, such as minimizing the inefficient and less responsive use of public resources. Nonetheless, given that this study is analyzing a single case of one smart city project, its results and the implications from such have limited generalizability-more studies across different countries are required for more robust knowledge in the topic. Future studies need to explore challenges associated with citizen-generated data (Löfgren \& Webster, 2019). Citizen-sourced data platform may be problematic with respect to the quality of the data and sampling bias. Platforms like Qlue may offer better service maps for wealthy and better-educated neighbourhoods whilst providing only incomplete information about socio-economically marginalized areas.

\section{Acknowledgements}

Wonhyuk Cho received partial support from the National Research 
Foundation of Korea through a grant [NRF-2017S1A3A2065838] to work on this project. Sarah H. Bickerton's contribution to this article is partially supported by Faculty Research Grant [Grant ID: 221494] from the Victoria Business School.

\section{Appendix A}

\begin{tabular}{|c|c|c|c|}
\hline Service type & Description & Departments & Examples \\
\hline Damaged roads & Mitigation and repair of damaged roads & $\begin{array}{l}\text { Public Facility Maintenance Agency, Public Works Agency } \\
\text { (Satpol PP - in Bahasa) }\end{array}$ & $\begin{array}{l}\text { Pothole repair } \\
\text { Sidewalk repair } \\
\text { Median-strip repair }\end{array}$ \\
\hline $\begin{array}{l}\text { Drainage \& flo- } \\
\text { od mitiga- } \\
\text { tion }\end{array}$ & $\begin{array}{l}\text { Cleaning and repairing drainage } \\
\text { Flood prevention }\end{array}$ & Public Facility Maintenance Agency, Environmental Agency & $\begin{array}{l}\text { Cleaning clogged drains } \\
\text { Dredging }\end{array}$ \\
\hline $\begin{array}{l}\text { Illegal adver- } \\
\text { tising }\end{array}$ & $\begin{array}{l}\text { Removing unauthorized advertising from public facil- } \\
\text { ities }\end{array}$ & Public Facility Maintenance Agency & $\begin{array}{l}\text { Removing unauthorized advertisements } \\
\text { Removing unauthorized banners }\end{array}$ \\
\hline Illegal parking & $\begin{array}{l}\text { Coordinating with other agencies to control vehicles that } \\
\text { are parked in prohibited areas. }\end{array}$ & $\begin{array}{l}\text { Public Order Agency, Transportation Agency, Police, Public } \\
\text { Facility Maintenance Agency }\end{array}$ & $\begin{array}{l}\text { Warning the vehicle owner } \\
\text { Issuance of fines } \\
\text { Vehicle towing }\end{array}$ \\
\hline $\begin{array}{l}\text { Illegal street ve- } \\
\text { ndors }\end{array}$ & $\begin{array}{l}\text { Overseeing street vendors to ensure compliance with } \\
\text { zoning requirements }\end{array}$ & $\begin{array}{l}\text { Public Facility Maintenance Agency, Public Order Agency, } \\
\text { Public Works Agency }\end{array}$ & $\begin{array}{l}\text { Relocation of street vendors } \\
\text { Coordination with other agencies to en- } \\
\text { sure street vender compliance }\end{array}$ \\
\hline Local election & $\begin{array}{l}\text { This service is similar to that for illegal advertising, but } \\
\text { specific to local election campaigns }\end{array}$ & Public Facility Maintenance Agency & $\begin{array}{l}\text { Removing unauthorized campaign flyers } \\
\text { and banners }\end{array}$ \\
\hline Public utility & $\begin{array}{l}\text { Following up on reports from citizens regarding public } \\
\text { utilities }\end{array}$ & $\begin{array}{l}\text { Public Facility Maintenance Agency, All related agencies } \\
\text { (electricity, water, police, transportation, forestry) }\end{array}$ & $\begin{array}{l}\text { Repairing broken street lighting } \\
\text { Fallen tree removal } \\
\text { Repairing/replacing damaged road signs }\end{array}$ \\
\hline $\begin{array}{l}\text { Traffic conges- } \\
\quad \text { tion }\end{array}$ & Coordination with other agencies to control traffic flow. & $\begin{array}{l}\text { Transportation Agency, Police, Public Order Agency, Public } \\
\text { Facility Maintenance Agency }\end{array}$ & $\begin{array}{l}\text { Peak hour intersection control, Public } \\
\text { transport safety compliance }\end{array}$ \\
\hline Code Violation & $\begin{array}{l}\text { Coordination with other agencies to handle citizen } \\
\text { reports of offences (traffic violations, vandalism, etc). }\end{array}$ & $\begin{array}{l}\text { Public Facility Maintenance Agency, Transportation } \\
\text { Agency, Police, Public Order Agency, Public Works Agency }\end{array}$ & $\begin{array}{l}\text { Enforcing traffic safety compliance, } \\
\text { Graffiti removal }\end{array}$ \\
\hline Waste disposal & $\begin{array}{l}\text { Domestic waste disposal via citizen request and/or non- } \\
\text { removal by the Environment Agency. }\end{array}$ & Public Facility Maintenance Agency, Environment Agency & $\begin{array}{l}\text { Sidewalk rubbish removal, Roadside } \\
\text { weed \& rubbish removal }\end{array}$ \\
\hline Other & $\begin{array}{l}\text { Those miscellaneous citizen reports not included in the } \\
\text { above categories }\end{array}$ & $\begin{array}{l}\text { Police, TransJakarta Bus Co., Social Affairs Agency, } \\
\text { Transportation Agency, Public Works Agency }\end{array}$ & $\begin{array}{l}\text { Detaining/rehabilitating homeless, } \\
\text { Maintainance of the TransJakarta bus- } \\
\text { way. }\end{array}$ \\
\hline
\end{tabular}

\section{References}

Akbar, D. (2015). Qlue: Cara mudah curhat kondisi seputar Ibukota. (PCPlus Online, April 20).

Qlue - Smartcity (2017). Retrieved from www.qlue.co.id.

Ministry of Home Affairs (2015). Profil Jakarta.

Adelekan, I., Johnson, C., Manda, M., Matyas, D., Mberu, B, Parnell, S, Pelling, M. Satterthwaite, D., \& Vivekananda, J. (2015). Disaster risk and its reduction: An agenda for urban Africa. International Development Planning Review, 37(1), 33-43.

Aguilera, U., Peña, O., Belmonte, O., \& López-de-Ipiña, D. (2017). Citizen-centric data services for smarter cities. Futur. Gener. Comput. Syst. 76, 234-247.

Albino, V., Berardi, U., \& Dangelico, R. M. (2015). Smart cities: Definitions, dimensions, performance, and initiatives. J. Urban Technol. 22(1), 3-21.

Alford, J. (2002). Who do public-sector clients coproduce? Toward a contingency theory. Adm. Soc. 34, 32-56.

Alford, J. (2009). Engaging public sector clients: From service-delivery to co-production Basingstoke, UK: Palgrave Macmillan.

Allen, B., Juillet, L., Miles, M., Paquet, G., Roy, J., \& Wilkins, K. (2004). The Organizatonal Culture of Digital Government: Technology, Accountability \& Shared Governance. Digital government: Principles and best practices (pp. 78-96). Igi Global.

Allen, B. A., Juillet, L., Paquet, G., \& Roy, J. (2001). E-Governance \& government on-line in Canada: Partnerships, people \& prospects. Government Information Quarterly, 18(2), 93-104.

Allen, B. A., Juillet, L., Paquet, G., \& Roy, J. (2005). E-government as collaborative governance: Structural, accountability and cultural reform. Practicing e-government: A global perspective (pp. 1-15). IGI Global.

Allen, B., \& Wade, E. (2011). Leadership for commissioning in an era of reform. Public Money \& Management, 31(5), 311-314.

Ananta, Y. (2017). Qlue Bikin Warga-Pemprov Makin Tidak Berjarak. Indonesia: Media.

Anggraini, E. (2016). Qlue connects people to Bureaucrats for a Better Jakarta. Asia: Digital News.

Arnstein, S. (1969). A ladder of citizen participation. J. Am. Plan. Assoc. 35(4), 216-224.

Attard, J., Orlandi, F., Scerri, S., \& Auer, S. (2015). A systematic review of open government data initiatives. Gov. Inf. Q. 32(4), 399-418.

Beierle, T. C., \& Cayford, J. (2002). Democracy in practice: Public participation in environmental decisions. Washington, DC: Resources for the Future.

Berry, L. L., Zeithaml, V. A., \& Parasuraman, A. (1990). Five imperatives for improving service quality. Sloan Manag. Rev. 31(4), 29-38.

Bertot, J. C., Jaeger, P. T., \& Grimes, J. M. (2010). Using ICTs to create a culture of transparency: E-government and social media as openness and anti-corruption tools for societies. Gov. Inf. Q. 27(3), 264-271.

Bovaird, T. (2007). Beyond engagement and participation: User and community coproduction of public services. Public Adm. Rev. 67(5), 846-860.

Brudney, J., \& England, R. (1983). Toward a definition of the coproduction concept. Public Adm. Rev. 43(1).

Bryson, J. M., Quick, K. S., Slotterback, C. S., \& Crosby, B. C. (2013). Designing public participation processes. Public Adm. Rev. 73(1), 23-34.

Callahan, K. (2007). Citizen participation: Models and methods. Int. J. Public Adm. 30(11), 1179-1196.

Campbell, J. W. (2018). Efficiency, incentives, and transformational leadership: Understanding collaboration preferences in the public sector. Public Perform. Manag. Rev. 41(2), 277-299.

Campbell, J. W., \& Cho, W. (2014). Two faces of government-business relations during South Koreas developmental period. Korean Comparative Government Review, 18(1), 47-66.

Canares, M., Putri, D. A., Karlina, M., \& Tanaya, J. (2017). How do citizens benefit from a Smart City? A case study of Jakarta, Indonesia. Washington, DC: World Wide Web Foundation.

Chatfield, A. T., \& Reddick, C. G. (2018a). All hands on deck to tweet \#sandy: Networked governance of citizen coproduction in turbulent times. Gov. Inf Q 35(2), 259-272.

Chatfield, A. T., \& Reddick, C. G. (2018b). Customer agility and responsiveness through big data analytics for public value creation: A case study of Houston 311 on-demand services. Gov. Inf. Q. 35(2), 336-347.

Cho, W. (2017). Change and continuity in police organizations: Institution, legitimacy, and democratization. The Korean Journal of Policy Studies, 32(1), 149-174.

Cho, W., \& Ho, A. T. (2018). Does neighborhood crime matter? A multi-year survey study on perceptions of race, victimization, and public safety. International J. Law Crime Just. 55, 13-26.

Cho, W., Im, T., Porumbescu, G. A., Lee, H., \& Park, J. (2013). A cross-country study of the relationship between Weberian bureaucracy and government performance. International Review of Public Administration, 18(3), 115-137.

Dachland, D. (2016). Monitoring app Qlue helps Jakarta improve services, efficiency. The Jakarta Post.

Díaz, P., Carroll, J., \& Aedo, I. (2016). Coproduction as an approach to technologymediated citizen participation in emergency management. Future Internet, 8(3), 41.

Ebner, W., Leimeister, J. M., \& Krcmar, H. (2009). Community engineering for innovations: The ideas competition as a method to nurture a virtual community for in novations. R\&D Manag. 39(4), 342-356.

Edelmann, N., Krimmer, R., \& Parycek, P. (2008). Engaging youth through deliberative eparticipation: A case study. International Journal of Electronic Governance, 1(4), 385-399.

Feeney, M. K., \& Welch, E. W. (2012). Electronic participation technologies and perceived outcomes for local government managers. Public Manag. Rev. 14(6), 815-833.

Feroz Khan, G., Young Yoon, H., Kim, J., \& Woo Park, H. (2014). From e-government to social government: Twitter use by Korea's central government. Online Information 
Review, 38(1), 95-113.

Ferris, J. M. (1984). Coprovision: Citizen time and money donations in public service provision. Public Administration Review, 324-333.

Firmstone, J., \& Coleman, S. (2015). Public engagement in local government: The voice and influence of citizens in online communicative spaces. Inf. Commun. Soc. 18(6), 680-695.

Forbes, S. J. (2008). The effect of service quality and expectations on customer complaints. J. Ind. Econ. 56(1), 190-213.

Glaeser, E. L., Hillis, A., Kominers, S. D., \& Luca, M. (2016). Crowdsourcing city government: Using tournaments to improve inspection accuracy. Am. Econ. Rev. 106(5), 114-118.

Harrison, S., \& Johnson, P. (2019). Challenges in the adoption of crisis crowdsourcing and social media in Canadian emergency management. Gov. Inf. Q. 36(3), 501-509 (July).

Hatry, H. (1999). Mini-symposium on intergovernmental comparative performance data. Public Adm. Rev. 59(2), 101-102.

Hetmank, L. (2013). Components and functions of crowdsourcing systems-a systematic literature review. Wirtschaftsinformatik, 4, 2013.

Hilgers, D., \& Ihl, C. (2010). Citizensourcing: Applying the concept of open innovation to the public sector. Int. J. Public Participation, 4(1).

Ho, A. T. K. (2002). Reinventing local governments and the e-government initiative. Public Adm. Rev. 62(4), 434-444.

Ho, A. T., \& Cho, W. (2017). Government communication effectiveness and satisfaction with police performance: A large-scale survey study. Public Adm. Rev. 77(2), 228-239.

Holgersson, J., \& Karlsson, F. (2014). Public e-service development: Understanding citizens' conditions for participation. Gov. Inf. Q. 31(3), 396-410.

Hossain, M., \& Kauranen, I. (2015). Crowdsourcing: A comprehensive literature review. Strategic Outsour. An International J. 8(1), 2-22.

Hur, J.-Y., Cho, W., Lee, G., \& Bickerton, S. H. (2019). The "smart work" myth: How bureaucratic inertia and workplace culture stymied digital transformation in the relocation of South Korea's capital. Asian Stud. Rev. 43(4), 691-709.

Im, T., \& Cho, W. (2010). Performance tools and their impact on pollution reduction: An assessment of environmental taxation and R\&D. International Review of Public Administration, 15(3), 53-65.

Im, T., Cho, W., \& Porumbescu, G. (2011). An empirical analysis of the relation between social spending and economic growth in developing countries and OECD members. Asia Pacific J. Public Administration, 33(1), 37-55.

Im, T., Cho, W., Porumbescu, G., \& Park, J. (2012). Internet, trust in government, and citizen compliance. J. Public Adm. Res. Theory, 24(3), 741-763.

Im, T., Lee, H., Cho, W., \& Campbell, J. W. (2014). Citizen preference and resource allocation: The case for participatory budgeting in Seoul. Local Gov. Stud. 40(1), $102-120$.

Johnston, E. W., \& Hansen, D. L. (2011). Design lessons for smart governance infrastructures. Transforming American governance: Rebooting the public square, 197-212.

Ombudsman Republik Indonesia (2015). Ringkasan Hasil Penelitian Kepatuhan Ombudsman RI Tahun. 2015

Islam, M. S. (2008). Towards a sustainable e-participation implementation model. Eur. J. ePract. 5(10), 1-12.

Jakobsen, M. (2013). Can government initiatives increase citizen coproduction? Results of a randomized field experiment. J. Public Adm. Res. Theory, 23, 27-54.

Jamal, A., Kizgin, H., Rana, N. P., Laroche, M., \& Dwivedi, Y. K. (2019). Impact of acculturation, online participation and involvement on voting intentions. Gov. Inf. Q. 36(3), 510-519.

Kang, Y., Cho, W., \& Jung, K. (2012). Does decentralization matter in health outcomes? Evidence from 22 OECD unbalanced panel data for 1995-2005. Int. Rev. Public Admin. 17(1), 1-32.

Kasymova, J. T., \& Schachter, H. L. (2014). Bringing participatory tools to a different level: A case study of local participatory practices in Kyrgyzstan. Public Perform. Manag. Rev. 37(2), 441-464.

Kelly, J. M., \& Swindell, D. (2002). A multiple-indicator approach to municipal service evaluation: Correlating performance measurement and citizen satisfaction across jurisdictions. Public Adm. Rev. 62(5), 610-621.

Kemp, S. (2017). The Full Guide to Southeast Asia's Digital Landscape in 2017. Techinasia.

Khan, G. F. (2017). Social media for government: A practical guide to understanding, implementing, and managing social media tools in the public sphere. Singapore: Springer.

Kim, N., \& Cho, W. (2014). Agencification and performance: The impact of autonomy and result-control on the performance of executive agencies in Korea. Public Performance \& Management Review, 38(2), 214-233.

Kishnani, N. (2014). The futurarc interview Ridwan Kamil Mayor. City of Bandung: FuturArc.

Lee, J., \& Kim, S. (2018). Citizens' e-participation on agenda setting in local governance: Do individual social capital and e-participation management matter? Public Manag. Rev. 20(6), 873-895.

Lee, J., \& Lee, H. (2014). Developing and validating a citizen-centric typology for smart city services. Gov. Inf. Q. 31, S93-S105.

Lee, T. D., Park, H., \& Lee, J. (2019). Collaborative accountability for sustainable public health: A Korean perspective on the effective use of ICT-based health risk communication. Gov. Inf. Q. 36(2), 226-236.

Lee, J. B., \& Porumbescu, G. A. (2019). Engendering inclusive e-government use through citizen IT training programs. Gov. Inf. Q. 36(1), 69-76.

Linders, D. (2012). From e-government to we-government: Defining a typology for citizen coproduction in the age of social media. Gov. Inf. Q. 29(4), 446-454.

Löfgren, K., \& Webster, C. W. R. (2019). Big data in government: the case of 'Smart Cities'. In A. Wilkinson, \& J. Storm Pedersen (Eds.). Big data: promise, application and pitfalls (pp. 133-148). Basingstoke: Edward Elgar.

Lucas, A. (2007). Jakarta's rubbish nightmare. Inside Indonesia.
Macintosh, A. (2004). Characterizing e-participation in policy-making. 37th Annual Hawaii International Conference on System Sciences, 2004. Proceedings.

Macintosh, A., Coleman, S., \& Schneeberger, A. (2009). eParticipation: The research gaps. International Conference on Electronic Participation (pp. 1-11). Berlin, Heidelberg: Springer (September).

Macintosh, A., \& Whyte, A. (2008). Towards an evaluation framework for eParticipation. Transforming Government: People, Process and Policy, 2(1), 16-30.

Maheshwari, D., \& Janssen, M. (2014). Reconceptualizing measuring, benchmarking for improving interoperability in smart ecosystems: The effect of ubiquitous data and crowdsourcing. Gov. Inf. Q. 31, S84-S92.

McBride, K., Aavik, G., Toots, M., Kalvet, T., \& Krimmer, R. (2019). How does open government data driven co-creation occur? Six factors and a 'perfect storm'; insights from Chicago's food inspection forecasting model. Gov. Inf. Q. 36(1), 88-97.

Medaglia, R. (2012). eParticipation research: Moving characterization forward (2006-2011). Gov. Inf. Q. 29(3), 346-360.

Meijer, A., \& Bolivar, M. (2016). Governing the smart city: A review of the literature on smart urban governance. Int. Rev. Adm. Sci. 82(2), 392-408.

Moynihan, D. P. (2003). Normative and instrumental perspective on public participation. Am. Rev. Public Adm. 33(2), 164-188.

Nam, T. (2012). Suggesting frameworks of citizen-sourcing via Government 2.0. Gov. Inf. Q. 29(1), 12-20.

Neirotti, P., De Marco, A., Cagliano, A. C., Mangano, G., \& Scorrano, F. (2014). Current trends in Smart City initiatives: Some stylised facts. Cities, 38, 25-36.

Neshkova, M. I., \& Guo, H. (2011). Public participation and organizational performance: Evidence from state agencies. J. Public Adm. Res. Theory, 22(2), 267-288.

Nurito (2016). Warga Apresiasi Kecepatan Respon Pengaduan di Qlue. Berita Jakarta.

Phang, C. W., \& Kankanhalli, A. (2008). A framework of ICT exploitation for E-partici pation initiatives. Commun. ACM, 51(12), 128-132.

Pirannejad, A., \& Janssen, M. (2019). Internet and political empowerment: Towards a taxonomy for online political empowerment. Inf. Dev. 35(1), 80-95.

Poister, T. H., Hall, J. L., \& Aristigueta, M. P. (2015). Managing and measuring performance in public and nonprofit organizations: An integrated approach (2nd ed.). John Wiley \& Sons.

Porumbescu, G. A. (2016). Placing the effect? Gleaning insights into the relationship between citizens' use of e-government and trust in government. Public Management Review, 18(10), 1504-1535.

Porumbescu, G. (2017). Not all bad news after all? Exploring the relationship between citizens' use of online mass media for government information and trust in government. International Public Management Journal, 20(3), 409-441.

Porumbescu, G. A., \& Grimmelikhuijsen, S. (2018). Linking decision-making procedures to decision acceptance and citizen coice: Evidence fFrom two studies. The American Review of Public Administration, 48(8), 902-914.

Reddick, C. G. (2011). Citizen interaction and e-government. Evidence for managerial, consultative, and participatory models. Transform. Gover. People Process Policy, 5(2), 167-184.

Sæbø, Ø., Rose, J., \& Flak, L. S. (2008). The shape of eParticipation: Characterizing an emerging research area. Government Information Quarterly, 25(3), 400-428.

Sagarik, D., Chansukree, P., Cho, W., \& Berman, E. (2018). E-government 4.0 in Thailand: The role of central agencies. Inform. Polity, 23(3), 343-353.

Savitri Hartono, H. (2018). Virtually (im)moral: Pious Indonesian Muslim women's use of Facebook. Asian Stud. Rev. 42(1), 39-52.

Scherer, S., Wimmer, M. A., \& Strykowski, S. (2015). Social government: A concept supporting communities in co-creation and co-production of public services. Proceedings of the 16th annual international conference on digital government research (pp. 204-209). ACM.

Schmidthuber, L., \& Hilgers, D. (2018). Unleashing innovation beyond organizational boundaries: Exploring citizensourcing projects. Int. J. Public Adm. 41(4), 268-283.

Setiawati, C. I., \& Pratiwi, P. M. (2015). Conceptual model of citizen's intention associated to e-government and internet behavior: Why do Bandung citizens follow the Mayor's social media? 3rd International Conference on Information and Communication Technology (ICoICT), Nusa Dua. 2015. 3rd International Conference on Information and Communication Technology (ICoICT), Nusa Dua (pp. 336-341).

Sharp, E. B. (1980). Toward a new understanding of urban services and citizen participation: The coproduction concept. Am. Rev. Public Adm. 124, 105-118.

Siagian, E. S., Sumaryana, A., Widianingsih, I., \& Nurasa, H. (2019). Public-private partnerships in solid waste management: Arrangements in Indonesia. Asia Pacific $J$. Public Administration, 41(1), 56-62.

Sobaci, M. Z. (Ed.). (2016). Social media and local governments: Theory and practice. Switzerland: Springer International.

Sorn-in, K., Tuamsuk, K., \& Chaopanon, W. (2015). Factors affecting the development of e-government using a citizen-centric approach. J. Sci. Technol. Policy Manag. 6(3), 206-222.

Stipak, B. (1979). Citizen satisfaction with urban services: Potential misuse as a performance indicator. Public Adm. Rev. 39(1), 46-52.

Susha, I., \& Grönlund, Å. (2012). eParticipation research: Systematizing the field. Gov. Inf. Q. 29(3), 373-382.

Syafputri, E. (2014). Jakarta Luncurkan Layanan Elektronik Smart City. Antaranews. https://www.antaranews.com/berita/469340/jakarta-luncurkan-layananelektronik-smart-city-.

Tai, K. T., Porumbescu, G., \& Shon, J. (2019). Can e-participation stimulate offline citizen participation: An empirical test with practical implications. Public Manag. Rev. 1-19.

Tang, T., \& Ho, A. T. K. (2019). A path-dependence perspective on the adoption of Internet of Things: Evidence from early adopters of smart and connected sensors in the United States. Gov. Inf. Q. 36(2), 321-332.

Thomsen, M. K. (2017). Citizen coproduction: The influence of self-efficacy perception and knowledge of how to coproduce. Am. Rev. Public Adm. 47(3), 340-353. 
Toots, M. (2019). Why E-participation systems fail: The case of Estonia's Osale.ee. Gov. Inf. Q. 36, 546-559.

United Nations (2016). United nations E-government survey 2016: E-government in support of sustainable development. New York: United Nations.

Van Ryzin, G. (2007). Pieces of a puzzle: Linking government performance, citizen satisfaction, and trust. Public Perform. Manag. Rev. 30(4), 521-535.

Voss, C. A., Roth, A. V., Rosenzweig, E. D., Blackmon, K., \& Chase, R. B. (2004). A tale of two Countries' conservatism, service quality, and feedback on customer satisfaction. J. Service Request, 6(3), 212-230.

Vu, K., \& Hartley, K. (2017). Promoting smart cities in developing countries: Policy insights from Vietnam. Telecommun. Policy, 41(10), 1-15.

Whitaker, G. P. (1980). Coproduction: Citizen participation in service delivery. Public Adm. Rev. 40(3), 240-246.

Wichowsky, A., \& Moynihan, D. P. (2008). Measuring how administration shapes citizenship: A policy feedback perspective on performance management. Public Adm. Rev. 68(5), 908-920.
Wirtz, B. W., \& Birkmeyer, S. (2015). Open government: Origin, development, and conceptual perspectives. Int. J. Public Adm. 38(5), 381-396.

World Bank (2012). Information and Communications for Development 2012: Maximizing Mobile. Washington, D.C.: World Bank.

Yang, K., \& Callahan, K. (2007). Citizen involvement efforts and bureaucratic responsiveness: Participatory values, stakeholder pressures, and administrative practicality. Public Adm. Rev. 67(2), 249-264.

Yang, K., \& Pandey, S. K. (2011). Further dissecting the black box of citizen participation: When does citizen involvement lead to good outcomes? Public Adm. Rev. 71(6), 880-892.

Yuliani, P. A. (2015). Memangkas Komunikasi Warga dengan Birokrat. Media Indonesia. Zheng, Y. (2016). The impact of E-participation on corruption: A cross-country analysis Int. Rev. Public Admin. 21(2), 91-103.

Zheng, Y. (2017). Explaining citizens' e-participation usage: Functionality of e-participation applications. Adm. Soc. 49(3), 423-442. 